Article

\title{
Study on the Effect of Second Injection Timing on the Engine Performances of a Gasoline/Hydrogen SI Engine with Split Hydrogen Direct Injecting
}

\author{
Guanting Li, Xiumin Yu, Ping Sun * and Decheng Li \\ State Key Laboratory of Automotive Simulation and Control, Jilin University, Renmin Street 5988, \\ Changchun 130022, Jilin, China; ligt18@mails.jlu.edu.cn (G.L.); yuxm@jlu.edu.cn (X.Y.); \\ lide199510@163.com (D.L.) \\ * Correspondence: sunping@jlu.edu.cn
}

Received: 15 September 2020; Accepted: 5 October 2020; Published: 7 October 2020

\begin{abstract}
Split hydrogen direct injection (SHDI) has been proved capable of better efficiency and fewer emissions. Therefore, to investigate SHDI deeply, a numerical study on the effect of second injection timing was presented at a gasoline/hydrogen spark ignition (SI) engine with SHDI. With an excess air ratio of 1.5, five different second injection timings achieved five kinds of hydrogen mixture distribution (HMD), which was the main factor affecting the engine performances. With SHDI, since the HMD is manageable, the engine can achieve better efficiency and fewer emissions. When the second injection timing was $105^{\circ}$ crank angle (CA) before top dead center (BTDC), the $P_{\max }$ was the highest and the position of the $\mathrm{P}_{\max }$ was the earliest. Compared with the single hydrogen direct injection (HDI), the $\mathrm{NO}_{X}, \mathrm{CO}$ and $\mathrm{HC}$ emissions with SHDI were reduced by $20 \%, 40 \%$ and $72 \%$ respectively.
\end{abstract}

Keywords: hydrogen direct injection; split injection; second injection timing; hydrogen mixture distribution; combustion; emission

\section{Introduction}

With the improvement of the world's industrial level, the consumption of fossil fuels is increasing year by year and the energy crisis is increasingly intensified. At the same time, the burning of fossil fuels also leads to a large number of harmful emissions, such as $\mathrm{NO}_{\mathrm{X}}, \mathrm{HC}, \mathrm{PM}$, etc. Therefore, how to improve the efficiency of engines and reduce fuel consumption and reduce harmful emissions has become a technical problem for all countries. Finding clean, efficient and renewable fuels is one of the ways to alleviate the energy crisis and environmental problems.

Hydrogen is considered one of the most promising alternatives to fossil fuels because it is widely available and renewable. However, the pure hydrogen engine still has big technical bottlenecks to be solved [1]. Hydrogen is more suitable as a kind of blending fuel for the spark ignition (SI) engine. Firstly, hydrogen has lower ignition energy than gasoline. Secondly, the flame propagation speed of hydrogen is faster, which can speed up the combustion and increase the engine efficiency [2]. Thirdly, hydrogen has a shorter wall quenching distance, which can reduce hydrocarbon (HC) emission [3]. Hydrogen has a wider flammability limit than gasoline, so it is easier to achieve lean burn combustion with hydrogen.

Ji et al. studied a hydrogen/gasoline engine with hydrogen injected into the intake-port and gasoline injected into the cylinder directly [4-11]. The results show that the performance was improved by adding hydrogen, especially under the lean burn condition [4,5]. By injecting hydrogen into the engine, the lean burn limit can be extended and the brake mean effective pressure can be increased $[6,7]$. 
The emissions were reduced by injecting hydrogen into the engine. The addition of hydrogen greatly reduced $\mathrm{HC}$ and $\mathrm{PM}$ emissions but increased $\mathrm{NO}_{\mathrm{X}}$ emissions [8]. In the cold starting condition, injecting hydrogen can reduce emissions during the cold starting process, but it will lead to an increase of $\mathrm{NO}_{X}$ emission [9]. By adding hydrogen, the idle speed and the fuel consumption can be reduced [10]. Hydrogen addition cannot improve the engine performance at high loads [11].

Huang et al. investigated the natural gas-hydrogen SI engine with mixture direct injection [12-16]. They found that, with hydrogen addition, the combustion of the engine becomes faster and the emissions are fewer. The early flame growth is more stable and faster under the lean burn condition after adding hydrogen.

Yu et al. have done a lot of research on a single hydrogen direct injection (HDI) SI engine in the past few years. According to their studies, the addition of hydrogen can accelerate the flame propagation speed in the cylinder, advance the optimal ignition advance angle and make the combustion completer and more stable, which can significantly reduce the engine's cycle-by-cycle variations [17-21]. With hydrogen, the engine could achieve low $\mathrm{HC}$ and $\mathrm{CO}$ emissions. Hydrogen addition increases the combustion temperature, which leads to an increase of $\mathrm{NO}_{\mathrm{X}}$ emissions [22-24]. To solve the problem of high $\mathrm{NO}_{\mathrm{X}}$ emission after injecting hydrogen into the engine, exhaust gas recirculation (EGR) was used to restrain the increase of $\mathrm{NO}_{\mathrm{x}}[25]$.

In [26], Li et al. did a comparative study of homogenous hydrogen mixture and stratified hydrogen mixture and found that the stratified hydrogen mixture had higher thermal efficiency and lower HC and $\mathrm{CO}$ emissions than the homogenous hydrogen mixture, especially under the lean combustion condition and found that the main factor affecting the performance of the hydrogen/gasoline SI engine was the hydrogen mixture distribution (HMD). When the HMD is homogenous, the combustion is complete and the emissions are reduced. When the HMD is stratified, the combustion can be accelerated and efficiency is higher. To achieve lower emissions and higher efficiency, a new kind of injection mode was found. In [27], Li et al. studied the effects of split injection of hydrogen in the cylinder on engine performance and found that split hydrogen direct injection (SHDI) could achieve the best performance in all kinds of hydrogen injection modes. SHDI could form a better HMD. The first injection could form a homogenous HMD, and the second injection could form a stratified HMD. As a result, the SHDI achieved lower emissions and higher efficiency.

The HMD in the cylinder was hard to measure by experiment. Numerical simulation is a good way to investigate the principles of HMD. In recent years, many numerical studies of hydrogen blended SI engines have been done.

Gong et al. have published several papers about a hydrogen/methanol SI engine [28-33]. With hydrogen addition, cylinder pressure increased and all are emissions reduced.

In [34], Shang et al. studied the effect of hydrogen addition to a hydrogen $\backslash$ n-butanol SI engine. With more hydrogen addition, $\mathrm{HC}, \mathrm{CO}$, acetaldehyde and formaldehyde emissions were all reduced continually.

There are few studies investigating the effects of HMD on a hydrogen\gasoline SI engine with SHDI. In [35], we investigated the split injection proportion of SHDI and found that HMD is the main factor affecting engine performance. To deeply investigate how SHDI achieves better engine performance, a numerical study on the effect of second injection timing was presented. Five different second injection timings achieved five different kinds of HMD in a SI engine with SHDI. The results proved that SHDI can achieve better efficiency and fewer emissions.

\section{Proposed Models and Validation}

\subsection{Computational Model}

The parameters of the engine are shown in Table 1. Figure 1 shows the 3D computation model in CONVERGE (V2.3, Convergent Science, Madison, Wisconsin, USA). The grid document is the same as 
in our former research and was tested for grid independence in [34] to ensure the accuracy and ability of the model to meet the requirements.

Table 1. Engine specifications.

\begin{tabular}{cc}
\hline Item & Characteristics \\
\hline & Four Cylinders; \\
Engine Type & Dual Injection; \\
& Spark Ignited \\
Bore $\times$ Stroke & $82.5 \mathrm{~mm} \times 92.8 \mathrm{~mm}$ \\
Compression Ratio & 9.6 \\
Displacement Volume & $1984 \mathrm{ml}$ \\
\hline
\end{tabular}

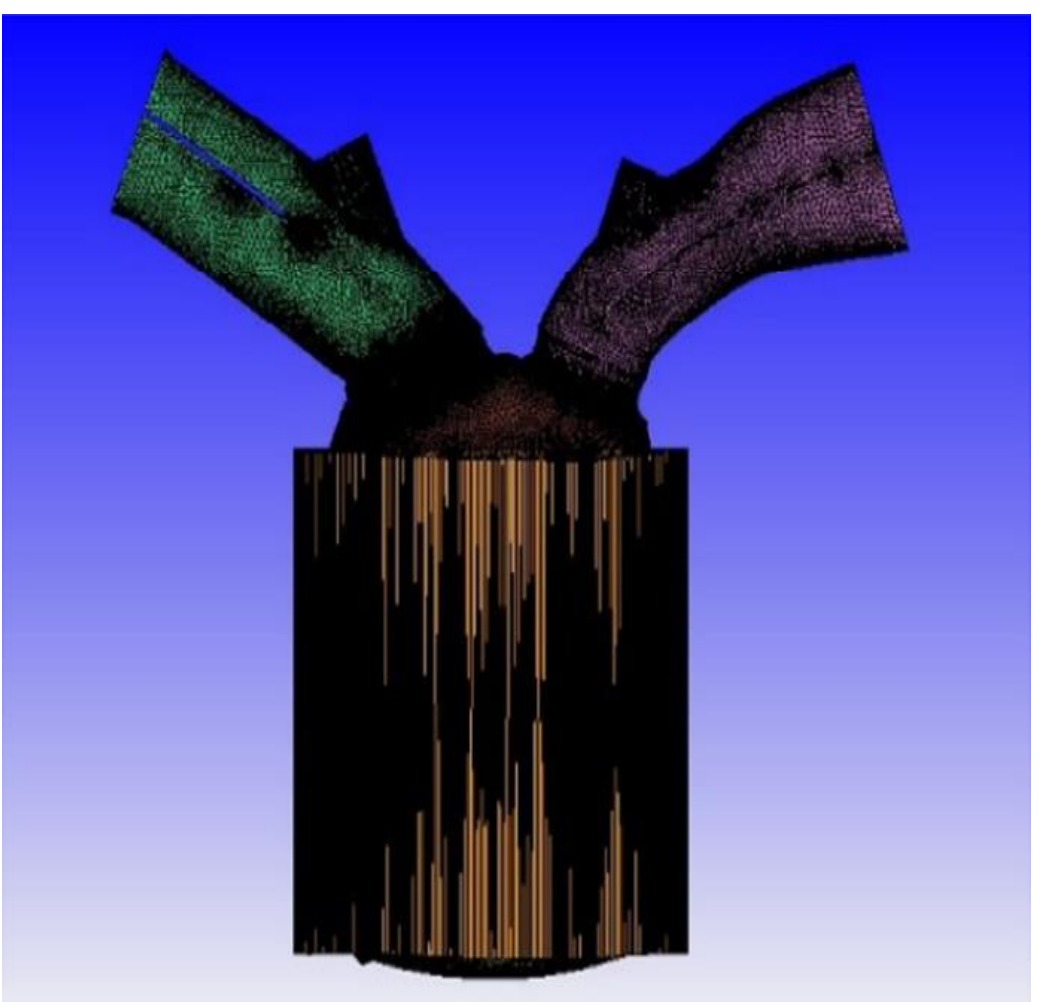

Figure 1. Single cylinder model.

Table 2 shows mathematical models of our model. The intake mixture was regarded as a homogeneous mixture with a certain proportion of oxygen, nitrogen and gasoline [36]. Six inflow boundaries were set to inject hydrogen directly [37].

Table 2. Mathematical models.

\begin{tabular}{cc}
\hline Turbulence model & RNG k- - Model \\
Ignition model & Spark-energy Deposition Model \\
Combustion model & SAGE Model \\
Heat transfer model & O'Rourke and Amsden Model \\
\hline
\end{tabular}

The combusting mechanism was a combination of a skeleton chemical reaction mechanism (48 components, 152 reactions) [38] and a detailed chemical reaction mechanism of hydrogen (10 components, 21 reactions) [39].

Table 3 shows the initial parameters. 
Table 3. Initial parameters.

\begin{tabular}{cc}
\hline Combustion chamber top surface & $550 \mathrm{~K}$ \\
Piston & $600 \mathrm{~K}$ \\
Intake port wall & $363 \mathrm{~K}$ \\
Exhaust port wall & $500 \mathrm{~K}$ \\
Cylinder wall & $450 \mathrm{~K}$ \\
Intake air & $363 \mathrm{~K}$ \\
Cylinder inside & $800 \mathrm{~K}$ \\
Inlet pressure & $0.035 \mathrm{MPa}$ \\
Outlet pressure & $0.1 \mathrm{MPa}$ \\
\hline
\end{tabular}

In this paper, five second injection timings from $75^{\circ} \mathrm{CA} B T D C$ to $135^{\circ} \mathrm{CA}$ BTDC were selected under the condition of $1200 \mathrm{rpm}$, a throttle opening of $10 \%$ and an excess air ratio of 1.5 . The direct injection pressure was set at $5 \mathrm{MPa}$, and the ignition timing was set at $15^{\circ} \mathrm{CA} \mathrm{BTDC}$.

There were two kinds of contrast tests: single HDI and pure gasoline. The $120^{\circ} \mathrm{CA}$ BTDC was proved to be the best injection timing for single HDI. Therefore, $120^{\circ} \mathrm{CA}$ BTDC was selected as the injecting timing of single HDI. For SHDI, the first hydrogen injection timing was $300^{\circ} \mathrm{CA} \mathrm{BTDC}$ and the hydrogen mass of the two injections was the same. Under these conditions, the engine can work stably. The hydrogen energy fraction was set at $20 \%$.

\subsection{Validation}

Figure 2 and Table 4 show the experimental setup scheme and measurement instruments.

Figure 3 shows the errors between the calculations and the experiment. The condition with single HDI was under the conditions of $1200 \mathrm{rpm}$, a throttle opening of $10 \%$, a direct injection pressure of $5 \mathrm{MPa}$, an ignition timing of $15^{\circ} \mathrm{CA} \mathrm{BTDC}$, a direct injection timing of $120^{\circ} \mathrm{CA} \mathrm{BTDC}$, a hydrogen energy fraction of $20 \%$ and an excess air ratio of 1.5 .

As shown in the figures, the simulation results are in good agreement with the experimental data.

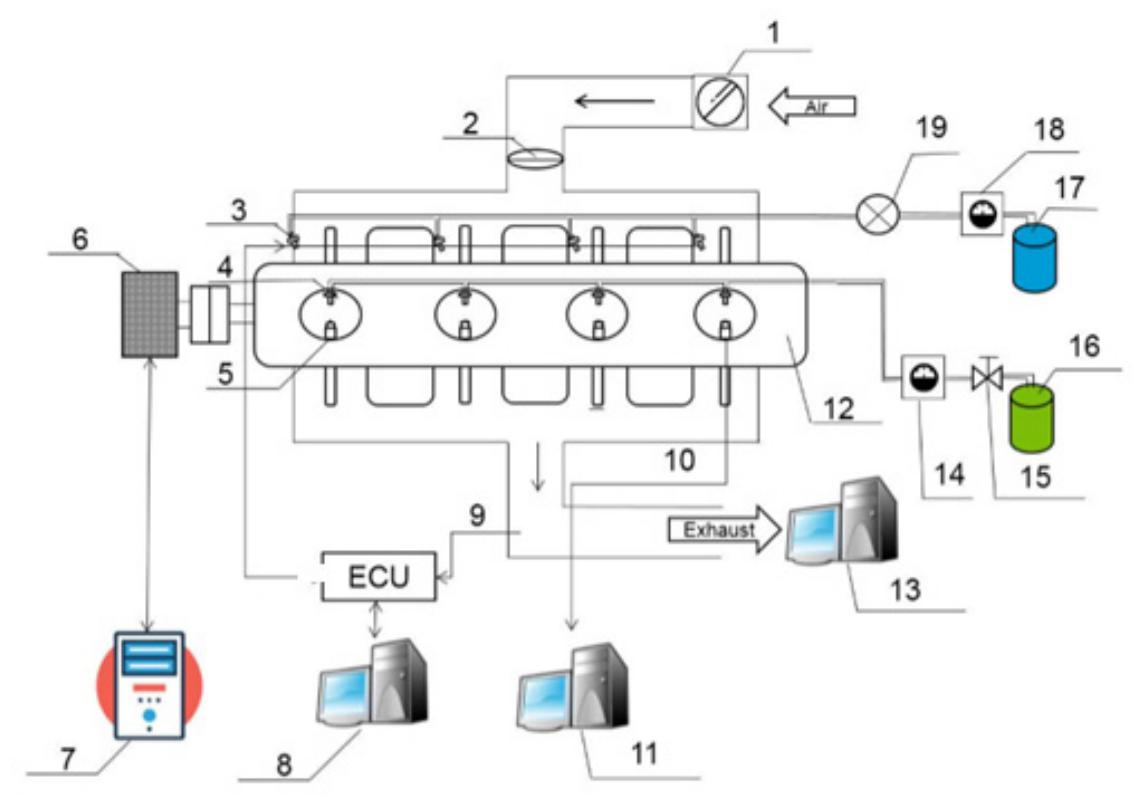

1. Air filter; 2. Electronic throttle valve; 3. Intake port injector; 4. Direct injector; 5. Spark plug; 6. Dynamometer; 7. Dynamometer control cabinet; 8. ECU PC; 9. i. sensor; 10. In-cylinder pressure transducer; 11. Combustion analyzer PC; 12. Engine; 13. Emissions analyzer; 14. Hydrogen mass flow meter; 15. Control valve; 16. Hydrogen bottle; 17. Gasoline tank; 18.

Fuel consumption meter; 19. Pump.

Figure 2. Experimental setup scheme. 
Table 4. Information on testing instruments.

\begin{tabular}{ccc}
\hline Measuring Project & Measurement Error & Production Type \\
\hline Speed & $\leq \pm 1 \mathrm{rpm}$ & CW160 \\
Brake power & $\leq \pm 0.4 \mathrm{~kW}$ & CW160 \\
Fuel consumption of gasoline & $\leq \pm 0.01 \mathrm{~g} / \mathrm{s}$ & Ono Sokki DF-2420 flow meter \\
Hydrogen volumetric flow meter & $\leq \pm 0.2 \%$ & DMF-1-1AB \\
Crank angle position & $\leq \pm 0.01^{\circ} \mathrm{CA}$ & Ono Sokki DS 9028 \\
Heat release rate & $\leq \pm 1 \%$ & Ono Sokki DS 9028 \\
Cylinder pressure & $\leq \pm 0.3 \mathrm{bar}$ & Ono Sokki DS 9028 \\
Flow pressure of intake air & $\leq \pm 0.1 \mathrm{kPa}$ & BOSCH flow meter \\
Excess air coefficient & $\leq \pm 0.15$ & LSU4.2 oxygen sensor \\
\hline
\end{tabular}
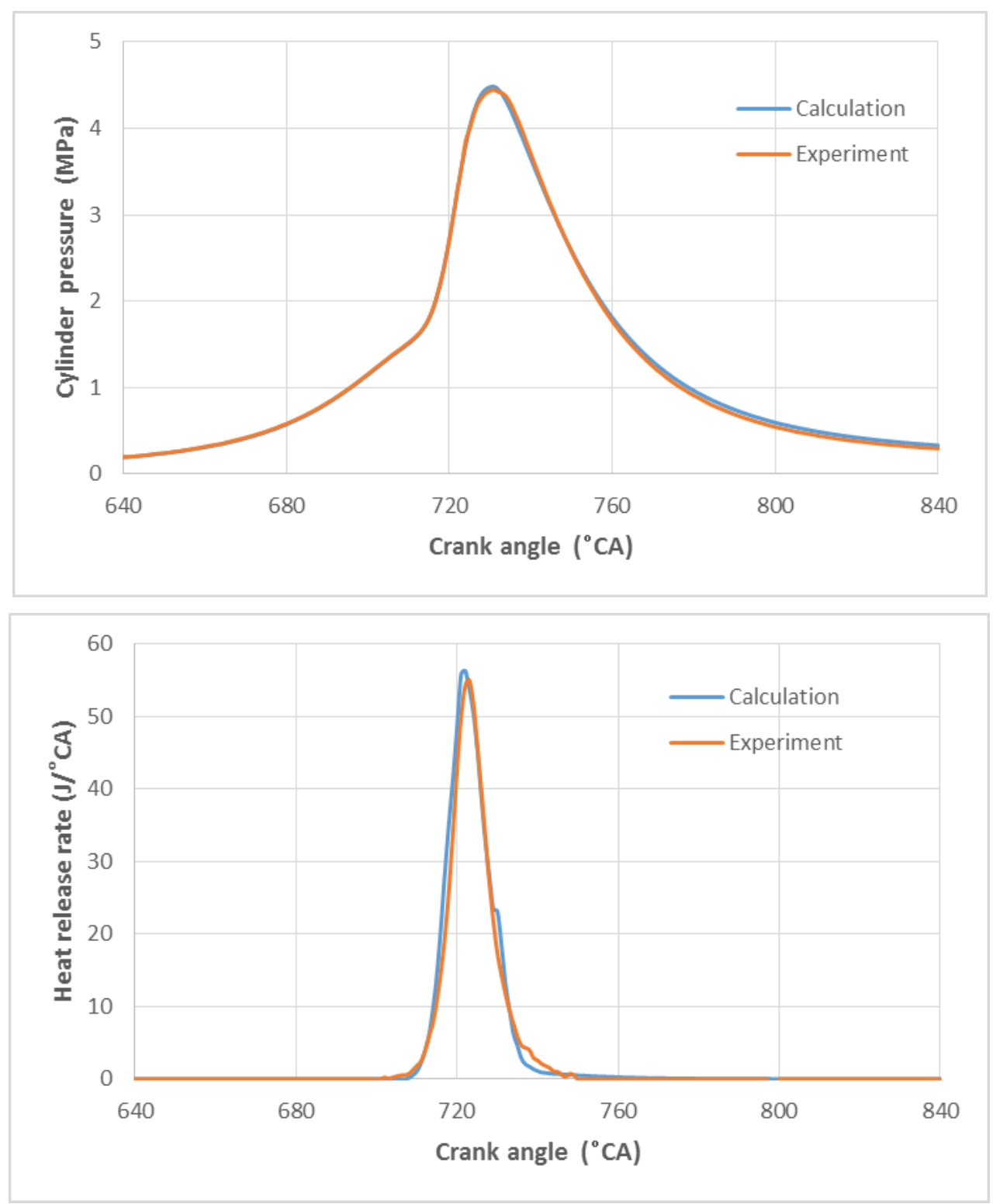

Figure 3. Model validation. 


\section{Results and Analysis}

\subsection{Hydrogen Mixture Distribution}

Figure 4 shows the change of the HMD at ignition timing with different second injection timings. The HMD of single HDI is rich in a small zone in the cylinder, and the HMD of SHDI is more homogenous.

Hydrogen mass fraction

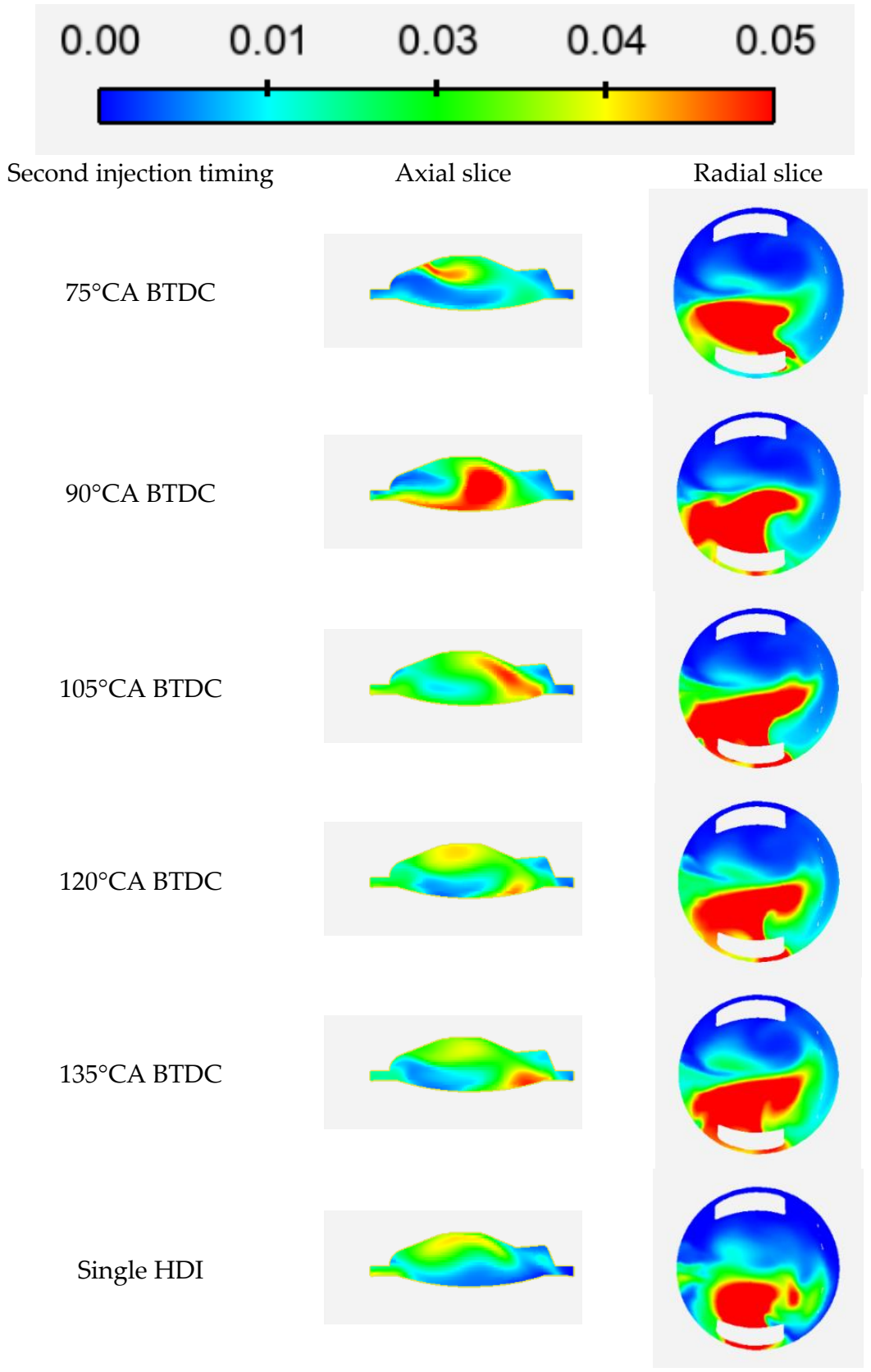

Figure 4. The change in the hydrogen mixture distribution (HMD) at ignition timing $15^{\circ}$ crank angle (CA) before top dead center (BTDC) with different second injection timings.

Hydrogen addition improves the efficiency of the engine in three main aspects: accelerating the ignition, accelerating the combustion rate and completing combustion [22]. Single HDI cannot do well in all aspects at the same time. Therefore, single HDI must balance the aspects to have high efficiency. 
As shown in Figure 4, the HMD of single HDI is rich near the spark plug, which can accelerate the ignition but cannot do well in other aspects. However, the HMD of SHDI is not only rich near the spark plug but also homogenous in other zones. By injecting hydrogen twice, SHDI can do well in all aspects. The rich mixture near the spark plug can accelerate the ignition, and the homogenous HMD can accelerate the combustion rate and complete the combustion. Since the first injection formed a more homogenous hydrogen mixture, the second injection should form a rich zone near the spark plug. As shown in the figure, early injection timing made the mixture too homogenous and late injecting timing made the mixture too rich on one side of the cylinder. As a result, there is a best second injection timing. In this work, it was $105^{\circ} \mathrm{CA} \mathrm{BTDC}$.

The too rich HMD of single HDI would cause high emissions. When it is combusting, the zone with rich mixture would have higher temperature and produce lots of $\mathrm{NO}_{\mathbf{X}}$ emissions. Furthermore, the $\mathrm{CO}$ and $\mathrm{HC}$ emissions cannot be burned completely since the hydrogen is too rich in a small zone and cannot do well in completing the combustion. However, SHDI reduces a great deal of emissions compared to single direct hydrogen injection. On the one hand, more homogenous HMD would reduce the peak temperature, which reduces $\mathrm{NO}_{X}$ emissions. On the other hand, with SHDI, the hydrogen affects a large zone in the cylinder to complete the combustion, which leads to low HC and $\mathrm{CO}$ emissions. In brief, SHDI can achieve low emissions.

\subsection{Combustion}

Figure 5 shows the change in cylinder pressure with different second injection timings. With hydrogen addition, the cylinder pressure increases obviously. Hydrogen addition improves the engine efficiency in three main ways: accelerating the ignition, speeding up the combustion rate and completing the combustion [22]. As the second injection timing advances, the cylinder pressure climbs to the highest value measured with a second injection timing of $105^{\circ} \mathrm{CA}$ BTDC. This is because early injecting timing would make the mixture too homogenous and late injecting timing would make the mixture too rich on one side of the cylinder. Since the best injection timing was set for single HDI, the pressure curve is higher than some pressure curves of SHDI but lower than the pressure curves for the second injection timings of $90^{\circ} \mathrm{CA} \mathrm{BTDC}, 105^{\circ} \mathrm{CA}$ BTDC and $120^{\circ} \mathrm{CA}$ BTDC. Split hydrogen direct injection can form better HMD.

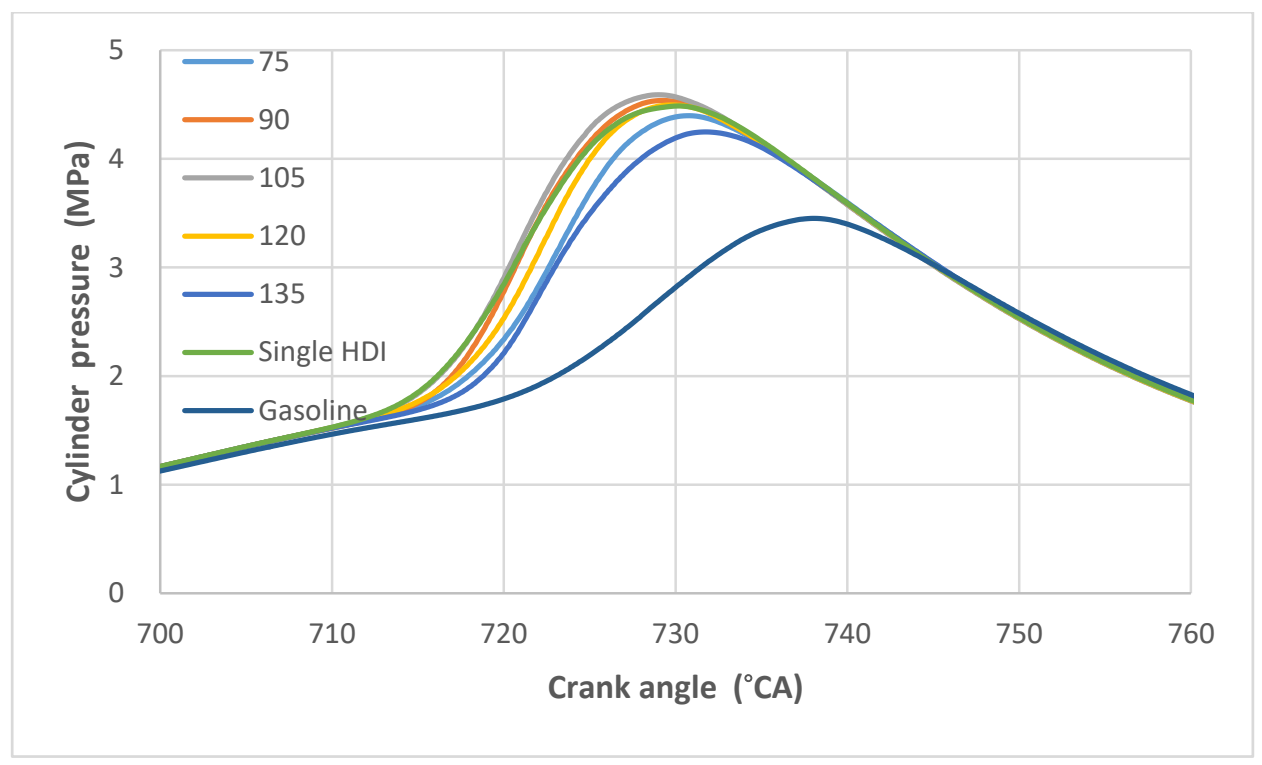

Figure 5. The change in cylinder pressure with different second injection timings. 
Figures 6 and 7 show the change of $P_{\max }$ and the position of $P_{\max }$ with different second injection timings. When the second injection timing is $105^{\circ} \mathrm{CA}$ BTDC, $\mathrm{P}_{\max }$ is the highest and the position of $P_{\max }$ is the earliest. Compared with gasoline, at the second injection timing of $105^{\circ} \mathrm{CA} B T D C$, the $\mathrm{P}_{\max }$ increases by $33 \%$ and the position of the $\mathrm{P}_{\max }$ advances by $9^{\circ} \mathrm{CA}$. With the second injection timing of $105^{\circ} \mathrm{CA}$ BTDC, the $\mathrm{P}_{\max }$ increases by $2.3 \%$ and the position of $\mathrm{P}_{\max }$ advances by $1.2^{\circ} \mathrm{CA}$ compared to single HDI.

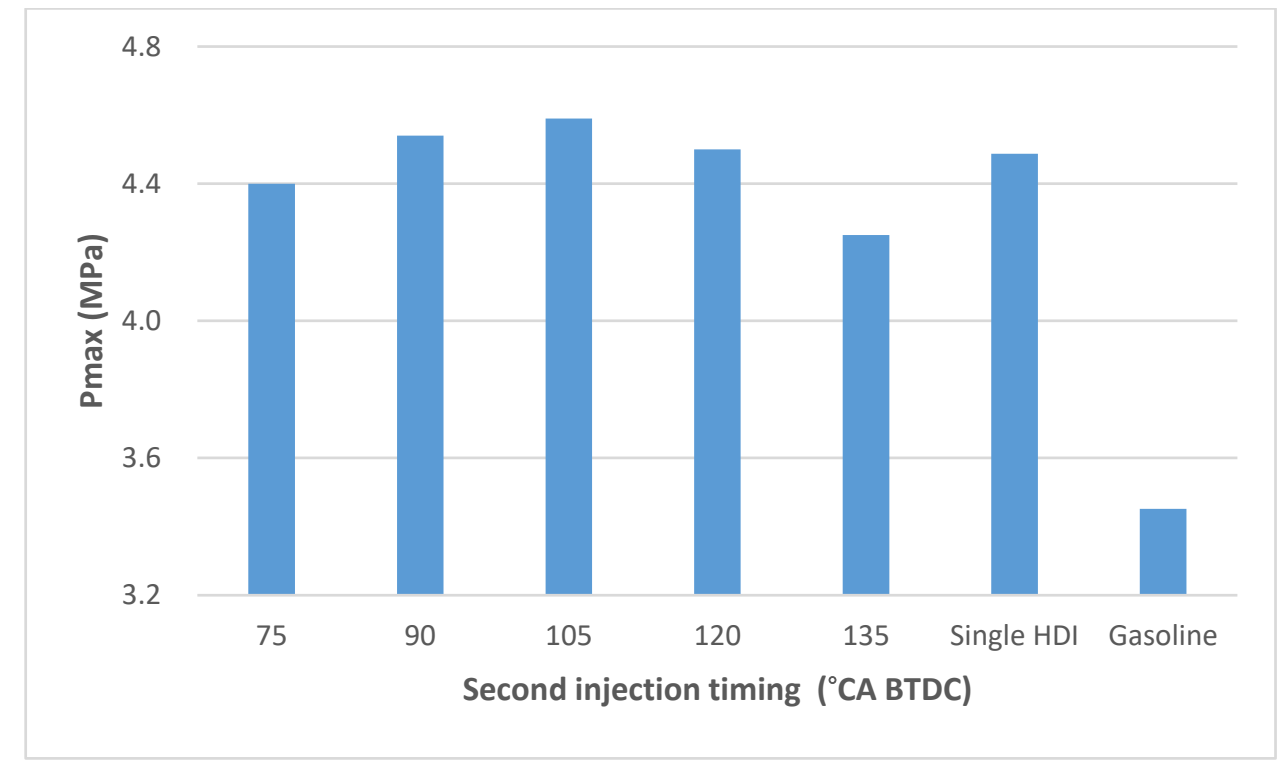

Figure 6. The change in $P_{\max }$ with different second injection timings.

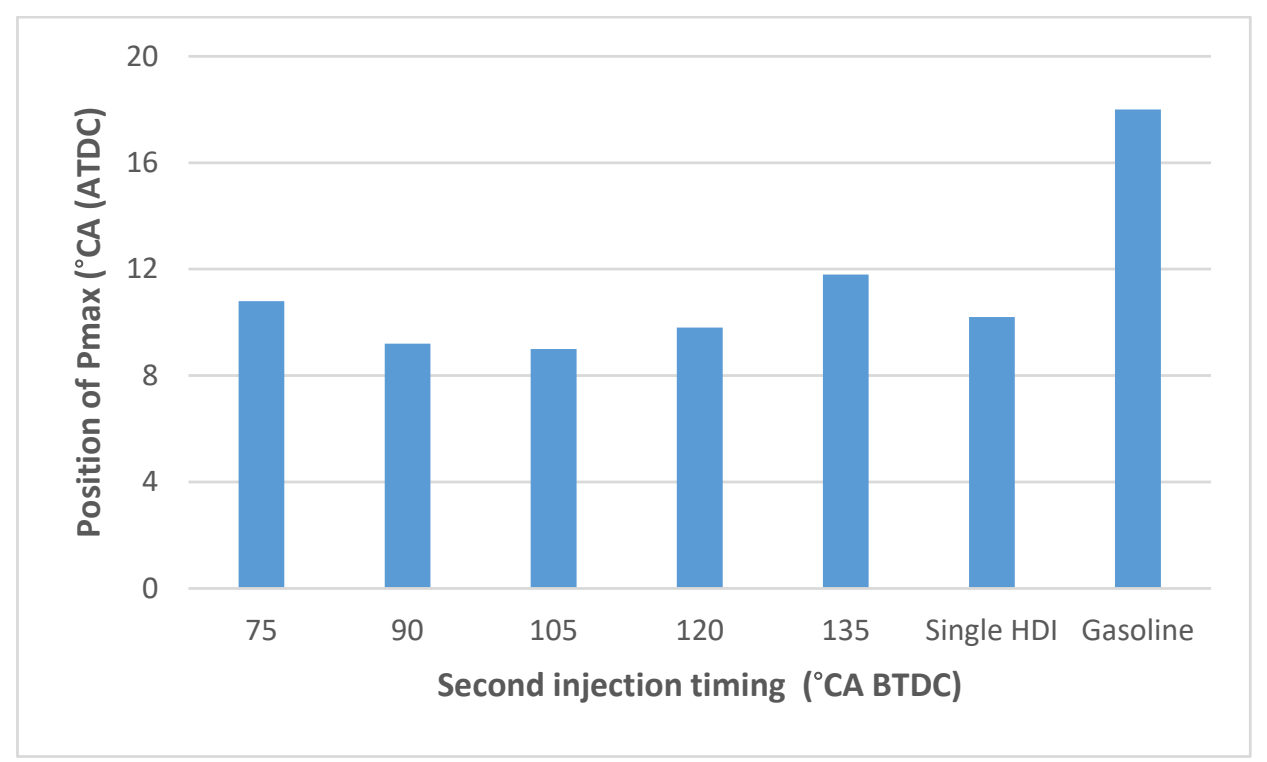

Figure 7. The change in the position of $\mathrm{P}_{\max }$ with different second injection timings.

Figure 8 shows the change in the heat release rate with different second injection timings. The heat release rate with hydrogen is more concentrated and advanced. As shown in Figure 8, the ignition with single HDI is the fastest. However, the most advanced maximum heat release rate is achieved by SHDI with a second hydrogen injection timing of $105^{\circ} \mathrm{CA}$ BTDC. This means that single hydrogen direct injection can only do well in accelerating the ignition, and SHDI can further speed up the combustion rate to improve the efficiency. 


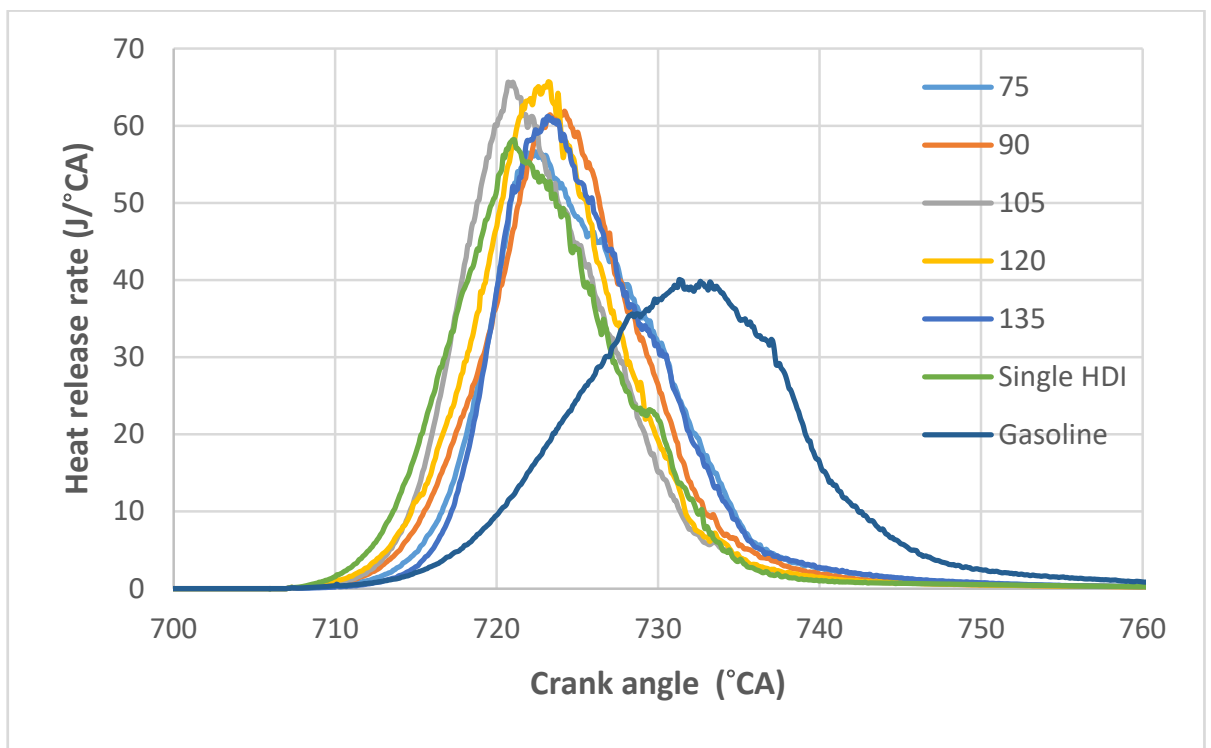

Figure 8. The change in the heat release rate with different second injection timings.

\subsection{Emissions}

Figure 9 shows the change of $\mathrm{NO}_{\mathrm{X}}$ emissions with different second injection timings. The temperature impacts $\mathrm{NO}_{X}$ emissions significantly. Since the flame temperature of hydrogen is higher than gasoline, the $\mathrm{NO}_{\mathrm{X}}$ emissions increase by $140 \%$ with hydrogen addition compared to gasoline [22]. Since the HMD of SHDI is more homogenous, the maximum temperature is less than that of single HDI [27]. Therefore, the $\mathrm{NO}_{\mathrm{X}}$ emissions with SHDI are fewer by an average of $20 \%$ compared to single HDI. As the second injection timing advances, the $\mathrm{NO}_{\mathrm{X}}$ emissions fluctuate in a narrow band.

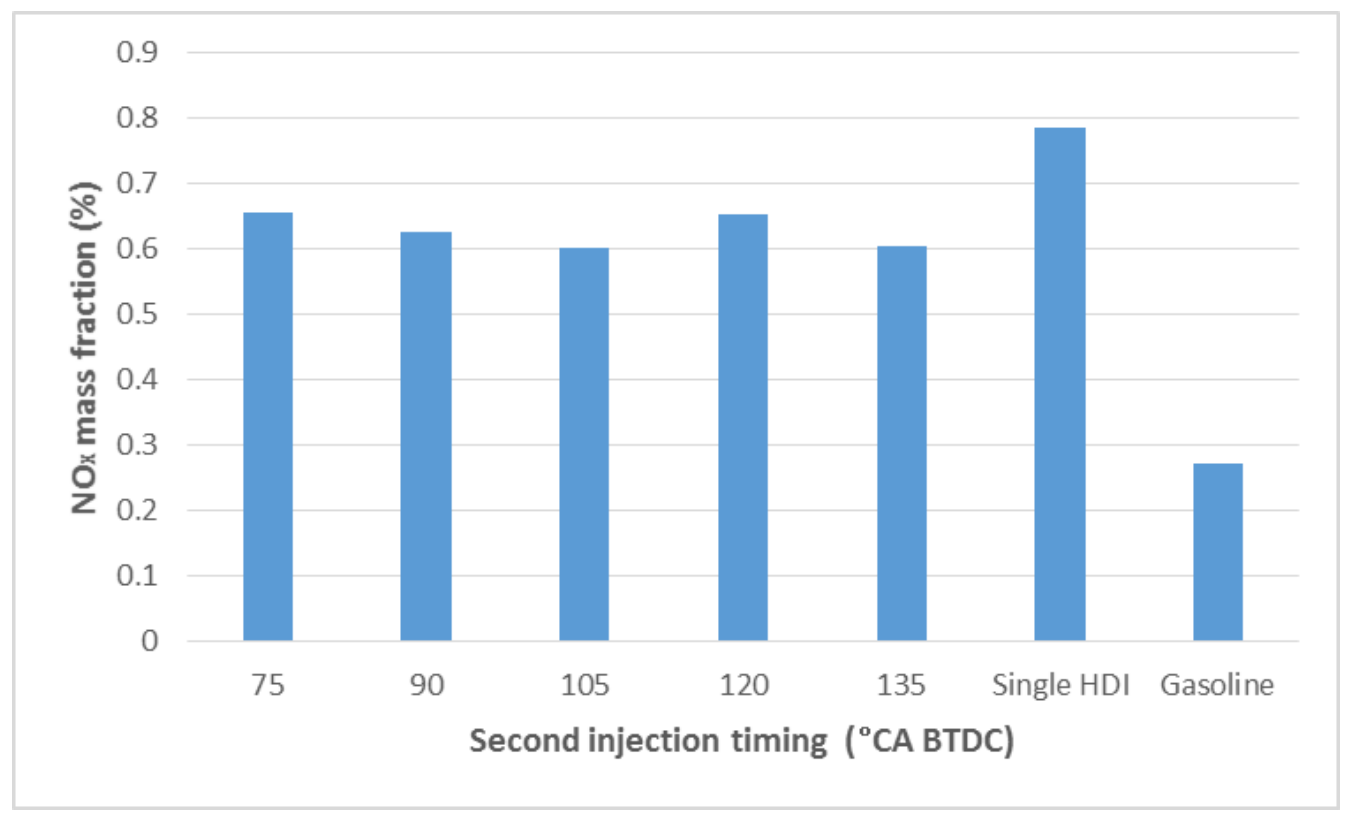

Figure 9. The change in $\mathrm{NO}_{X}$ emissions with different second injection timings.

Figure 10 shows the change in the conditions of $\mathrm{NO}_{\mathbf{X}}$ emissions and the change in temperature after combustion with different second injection timings, which could indicate a similarity between $\mathrm{NO}_{\mathrm{X}}$ emissions and temperature. With single HDI, the peak temperature is obviously higher, and the 
$\mathrm{NO}_{X}$ emissions are greater than those of SHDI. With SHDI, the homogenous HMD could reduce the size of the high temperature zone and produce fewer $\mathrm{NO}_{\mathrm{X}}$ emissions than single HDI.

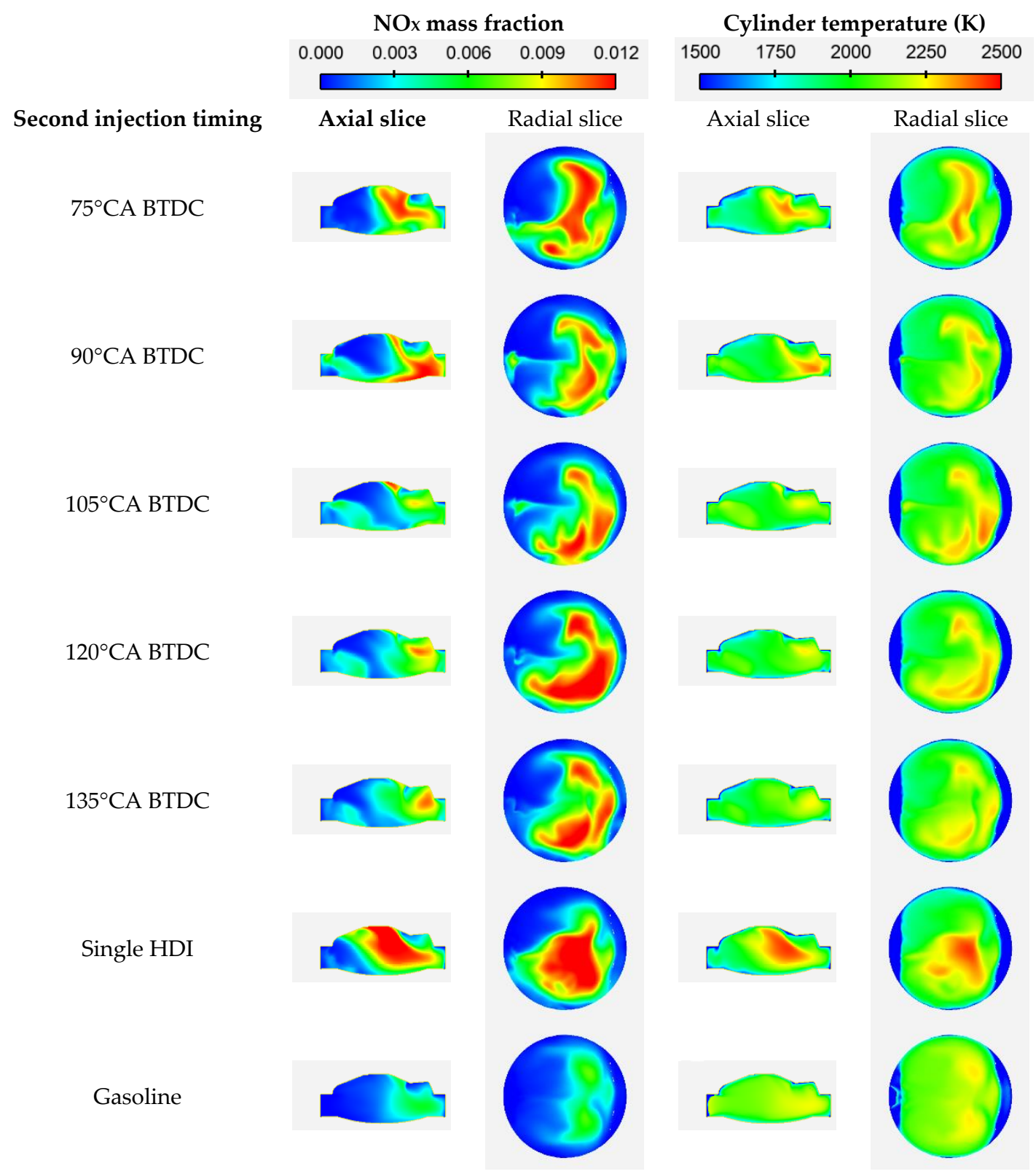

Figure 10. The change in the conditions of $\mathrm{NO}_{\mathrm{X}}$ emissions and the change in temperature after combustion with different second injection timings.

Figures 11 and 12 show the change in $\mathrm{CO}$ and $\mathrm{HC}$ emissions with different second injection timings. Due to completed combustion with hydrogen addition, $\mathrm{CO}$ and $\mathrm{HC}$ emissions are obviously reduced [22]. Since the HMD of single HDI is too rich and cannot affect most of the zone in the cylinder, single HDI cannot make full use of hydrogen to limit CO and HC emissions. However, the HMD of SHDI is more homogenous and hydrogen can affect the majority zone of the cylinder. As a result, SHDI produces fewer $\mathrm{CO}$ and $\mathrm{HC}$ emissions than does single HDI [27]. Compared with single HDI, $\mathrm{CO}$ and HC emissions with SHDI are respectively reduced by $40 \%$ and $72 \%$. As the second injection timing advances, the $\mathrm{CO}$ and $\mathrm{HC}$ emissions continue to decline. When the second injection timing is $135^{\circ} \mathrm{CA}$ BTDC, the CO and HC emissions respectively decrease by $20 \%$ and $40 \%$ compared to the second 
injection timing of $75^{\circ} \mathrm{CA}$ BTDC. As the injection of hydrogen makes the HMD more homogenous earlier, the hydrogen can affect a larger zone.

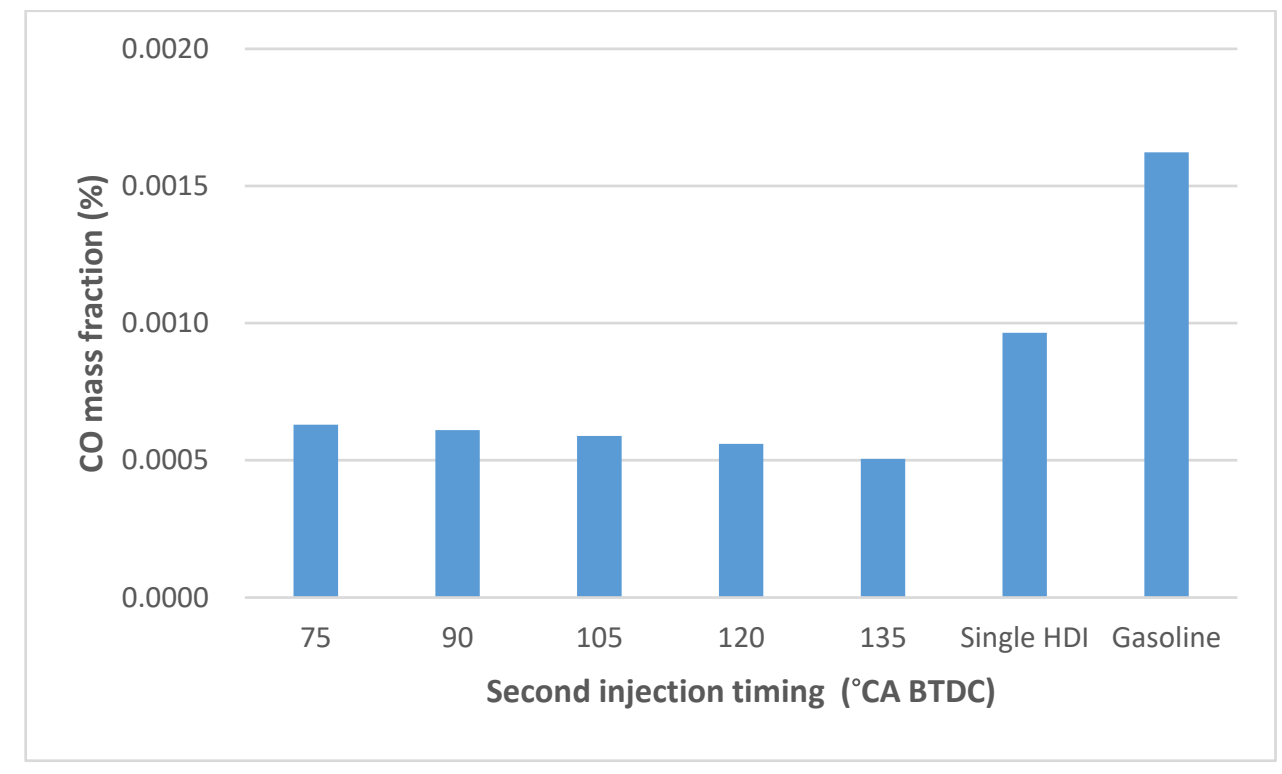

Figure 11. The change in $\mathrm{CO}$ emission with different second injection timings.

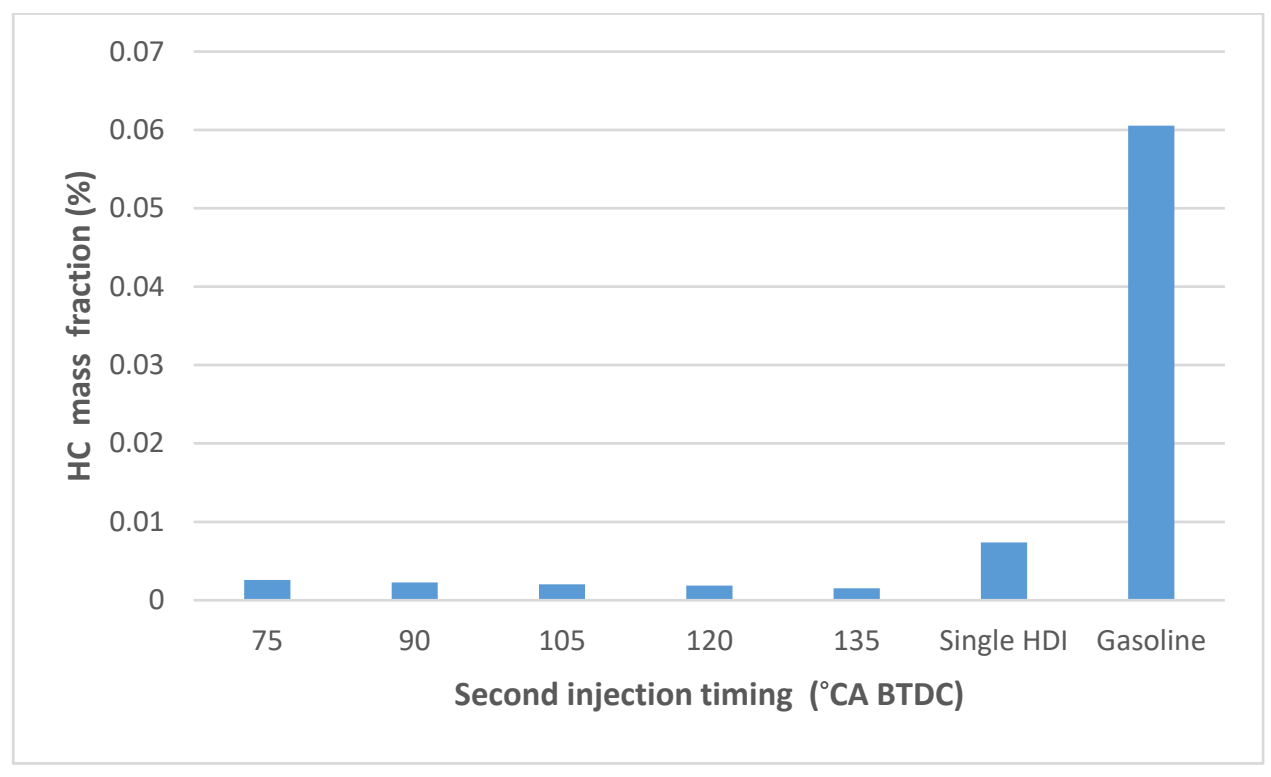

Figure 12. The change in $\mathrm{HC}$ emissions with different second injection timings.

\section{Conclusions}

In this study, by building a model that was validated in CONVERGE, the effects of second injection timing on HMD, combustion and emissions were investigated. With SHDI, the engine can simultaneously increase its efficiency and reduce emissions without additional cost. The main conclusions are as follows.

1. SHDI can form a better HMD. The HMD of SHDI is not only rich near the spark plug but also homogenous in other zones. Therefore, combustion can be accelerated and completed. As a result, SHDI can achieve better engine performance. 
2. With hydrogen addition, cylinder pressure increases obviously. The best second injection timing is $105^{\circ} \mathrm{CA} \mathrm{BTDC}$. This is because early injecting timing would make the mixture too homogenous and late injection timing would make the mixture too rich on one side of the cylinder. When the second injection timing is $105^{\circ} \mathrm{CA} \mathrm{BTDC}, \mathrm{P}_{\max }$ is the highest and the position of $\mathrm{P}_{\max }$ is earliest of all values measured.

3. $\mathrm{NO}_{\mathrm{X}}$ emissions increase by $140 \%$ after hydrogen addition compared to gasoline. $\mathrm{NO}_{\mathrm{X}}$ emissions with SHDI are reduced by an average of $20 \%$ compared to single HDI. The main reason is that the HMD of SHDI is more homogenous and the maximum temperature is lower compared to single HDI. As the second injection timing advances, the $\mathrm{NO}_{\mathrm{X}}$ emissions change a little.

4. CO and $\mathrm{HC}$ emissions are respectively reduced by $60 \%$ and $95 \%$ after hydrogen addition compared to gasoline. This is because the HMD of SHDI is more homogenous than that of HDI and hydrogen can affect the majority zone of the cylinder. Compared with single HDI, the CO and HC emissions with SHDI are respectively reduced by $40 \%$ and $72 \%$. As the second injection timing advances, the $\mathrm{CO}$ and $\mathrm{HC}$ emissions continue to decline. When the second injection timing is $135^{\circ} \mathrm{CA} \mathrm{BTDC}$, the $\mathrm{CO}$ and $\mathrm{HC}$ emissions respectively decrease by $20 \%$ and $40 \%$ compared to the emissions associated with a second injection timing of $75^{\circ} \mathrm{CA}$ BTDC.

Author Contributions: Conceptualization, G.L. and X.Y.; data curation, G.L. and D.L.; formal analysis, G.L.; funding acquisition, X.Y. and P.S.; investigation, G.L.; methodology, G.L. and X.Y.; resources, X.Y. and P.S.; supervision, X.Y.; writing_original draft, G.L.; writing—review and editing, X.Y., P.S. and D.L. All authors have read and agreed to the published version of the manuscript.

Funding: This research was funded by the National Natural Science Foundation of China (grant number 51976076) and the National Engineering Laboratory for Mobile Source Emission Control Technology (grant number NELMS2018A19).

Conflicts of Interest: The authors declare no conflict of interest.

\section{Abbreviations}

$\begin{array}{ll}\text { ATDC } & \text { After Top Dead Center } \\ \text { BTDC } & \text { Before Top Dead Center } \\ \text { CA } & \text { Crank Angle } \\ \text { CO } & \text { Carbon Monoxide } \\ \text { ECU } & \text { Electronic Control Unit } \\ \text { EGR } & \text { Exhaust Gas Recirculation } \\ \text { HC } & \text { Hydrocarbon } \\ \text { HDI } & \text { Hydrogen Direct Injection } \\ \text { HMD } & \text { Hydrogen Mixture Distribution } \\ \text { NO } & \text { Nitrogen Oxides } \\ \text { SHDI } & \text { Split Hydrogen Direct Injection } \\ \text { SI } & \text { Spark Ignition }\end{array}$

\section{References}

1. Kamil, M.; Rahman, M.M. Performance prediction of spark-ignition engine running on gasoline-hydrogen and methane-hydrogen blends. Appl. Energy 2015, 158, 556-567. [CrossRef]

2. Açıkgöz, B.; Çelik, C.; Soyhan, H.S.; Gökalp, B.; Karabă̆, B. Emission characteristics of an hydrogen-CH4 fuelled spark ignition engine. Fuel 2015, 159, 298-307. [CrossRef]

3. Ceviz, M.A.; Sen, A.K.; Küleri, A.K.; Öner, I.V. Engine performance, exhaust emissions, and cyclic variations in a lean-burn SI engine fueled by gasoline-hydrogen blends. Appl. Therm. Eng. 2012, 36, 314-324. [CrossRef]

4. Ji, C.; Wang, S.; Zhang, B.; Liu, X. Emissions performance of a hybrid hydrogen-gasoline engine-powered passenger car under the New European Driving Cycle. Fuel 2013, 106, 873-875. [CrossRef]

5. Wang, S.; Ji, C. Cyclic variation in a hydrogen-enriched spark-ignition gasoline engine under various operating conditions. Int. J. Hydrog. Energy 2012, 37, 1112-1119. [CrossRef] 
6. Ji, C.; Wang, S.; Zhang, B. Effect of spark timing on the performance of a hybrid hydrogen-gasoline engine at lean conditions. Int. J. Hydrog. Energy 2010, 35, 2203-2212. [CrossRef]

7. Ji, C.; Wang, S. Experimental study on combustion and emissions performance of a hybrid hydrogen-gasoline engine at lean burn limits. Int. J. Hydrog. Energy 2010, 35, 1453-1462. [CrossRef]

8. Ji, C.; Cong, X.; Wang, S.; Shi, L.; Su, T.; Wang, D. Performance of a hydrogen-blended gasoline direct injection engine under various second gasoline direct injection timings. Energy Convers. Manag. 2018, 171, 1704-1711. [CrossRef]

9. Hao, L.; Xu, X.; Guo, X.; Ji, C.; Wang, X.; Tan, J.; Ge, Y. Investigation of cold-start emission control strategy for a bi-fuel hydrogen/gasoline engine. Int. J. Hydrog. Energy 2016, 41, 18273-18281. [CrossRef]

10. Wang, S.; Ji, C.; Zhang, M.; Zhang, B. Reducing the idle speed of a spark-ignited gasoline engine with hydrogen addition. Int. J. Hydrog. Energy 2010, 35, 10580-10588. [CrossRef]

11. Ji, C.; Wang, S.; Zhang, B. Combustion and emissions characteristics of a hybrid hydrogen-gasoline engine under various loads and lean conditions. Int. J. Hydrog. Energy 2010, 35, 5714-5722. [CrossRef]

12. Huang, Z.; Wang, J.; Liu, B.; Zeng, K.; Yu, J.; Jiang, D. Combustion characteristics of a direct-injection engine fueled with natural gas-hydrogen mixtures. Energy Fuels 2006, 20, 540-546. [CrossRef]

13. Huang, Z.; Wang, J.; Liu, B.; Zeng, K.; Yu, J.; Jiang, D. Combustion characteristics of a direct-injection engine fueled with natural gas-hydrogen blends under various injection timings. Energy Fuels 2006, 20, 1498-1504. [CrossRef]

14. Wang, J.; Huang, Z.; Fang, Y.; Liu, B.; Zeng, K.; Miao, H.; Jiang, D. Combustion behaviors of a direct-injection engine operating on various fractions of natural gas-hydrogen blends. Int. J. Hydrog. Energy 2007, 32, 3555-3564. [CrossRef]

15. Wang, J.; Huang, Z.; Tang, C.; Zheng, J. Effect of hydrogen addition on early flame growth of lean burn natural gas-air mixtures. Int. J. Hydrog. Energy 2010, 35, 7246-7252. [CrossRef]

16. Wang, J.; Huang, Z.; Zheng, J.; Miao, H. Effect of partially premixed and hydrogen addition on natural gas direct-injection lean combustion. Int. J. Hydrog. Energy 2009, 34, 9239-9247. [CrossRef]

17. He, F.; Li, S.; Yu, X.; Du, Y.; Zuo, X.; Dong, W.; Sun, P.; He, L. Comparison study and synthetic evaluation of combined injection in a spark ignition engine with hydrogen-blended at lean burn condition. Energy 2018, 157, 1053-1062. [CrossRef]

18. Yu, X.; Zuo, X.; Wu, H.; Du, Y.; Sun, Y.; Wang, Y. Study on combustion and emission characteristics of a combined injection engine with hydrogen direct injection. Energy Fuels 2017, 31, 5554-5560. [CrossRef]

19. Shi, W.; Yu, X.; Zhang, H.; Li, H. Effect of spark timing on combustion and emissions of a hydrogen direct injection stratified gasoline engine. Int. J. Hydrog. Energy 2016, 42, 5619-5626. [CrossRef]

20. Yao, S.; Yu, X.; Dong, W.; Yang, T. Effects of hydrogen direct injection on engine stability and optimization of control parameters fora combined injection engine. Int. J. Hydrog. Energy 2018, 43, 6723-6733.

21. Yu, X.; Wu, H.; Du, Y.; Yang, T.; Liu, L.; Niu, R. Research on cycle-by-cycle variations of an SI engine with HDI under lean burn conditions. Appl. Therm. Eng. 2016, 109, 569-581. [CrossRef]

22. Du, Y.; Yu, X.; Wang, J.; Wu, H.; Dong, W.; Gu, J. Research on combustion and emission characteristics of a lean burn gasoline engine with hydrogen direct-injection. Int. J. Hydrog. Energy 2016, 41, 3240-3248. [CrossRef]

23. Niu, R.; Yu, X.; Du, Y.; Xie, H.; Wu, H.; Sun, Y. Effect of hydrogen proportion on lean burn performance of a dual fuel SI engine using hydrogen direct-injection. Fuel 2016, 186, 792-799. [CrossRef]

24. Sun, Y.; Yu, X.; Jiang, L. Effects of direct hydrogen injection on particle number emissions from a lean burn gasoline engine. Int. J. Hydrog. Energy 2016, 41, 18631-18640. [CrossRef]

25. Du, Y.; Yu, X.; Liu, L.; Li, R.; Zuo, X.; Sun, Y. Effect of addition of hydrogen and exhaust gas recirculation on characteristics of hydrogen gasoline engine. Int. J. Hydrog. Energy 2017, 42, 8288-8298. [CrossRef]

26. Yu, X.; Li, G.; Yu, X.; Guo, Z.; Shang, Z.; He, F.; Shen, Q.; Li, D.; Li, Y. A comparative study on effects of homogeneous or stratified hydrogen on combustion and emissions of a gasoline/hydrogen SI engine. Int. J. Hydrog. Energy 2019, 44, 25974-25984. [CrossRef]

27. Li, G.; Yu, X.; Shi, W.; Yao, C.; Wang, S.; Shen, Q. Effects of split injection proportion and the second injection timings on combustion and emissions of a dual fuel SI engine with SHDI. Int. J. Hydrog. Energy 2019, 44, 11194-11204. [CrossRef] 
28. Gong, C.; Li, Z.; Li, D.; Liu, J.; Si, X.; Yu, J.; Huang, W.; Liu, F.; Han, Y. Numerical investigation of hydrogen addition effects on methanol-air mixtures combustion in premixed laminar flames under lean burn conditions. Renew. Energy 2018, 127, 56-63. [CrossRef]

29. Gong, C.; Li, Z.; Chen, Y.; Liu, J.; Liu, F.; Han, J. Influence of ignition timing on combustion and emissions of a spark-ignition methanol engine with added hydrogen under lean-burn conditions. Fuel 2019, 2351, 227-238. [CrossRef]

30. Gong, C.; Li, Z.; Yi, L.; Liu, F. Comparative study on combustion and emissions between methanol port-injection engine and methanol direct-injection engine with $\mathrm{H} 2$-enriched port-injection under lean-burn conditions. Energy Convers. Manag. 2019, 200, 112096. [CrossRef]

31. Gong, C.; Li, Z.; Yi, L.; Huang, K.; Liu, F. Research on the performance of a hydrogen/methanol dual-injection assisted spark-ignition engine using late-injection strategy for methanol. Fuel 2020, 260, 116403. [CrossRef]

32. Gong, C.; Li, Z.; Yi, L.; Liu, F. Experimental investigation of equivalence ratio effects on combustion and emissions characteristics of an $\mathrm{H} 2 /$ methanol dual-injection engine under different spark timings. Fuel 2020, 262, 116463. [CrossRef]

33. Gong, C.; Li, Z.; Yi, L.; Sun, J.; Liu, F. Comparative analysis of various combustion phase control methods in a lean-burn $\mathrm{H} 2 /$ methanol fuel dual-injection engine. Fuel 2020, 262, 116592. [CrossRef]

34. Shang, Z.; Yu, X.; Shi, W.; Huang, S.; Li, G.; Guo, Z.; He, F. Numerical research on effect of hydrogen blending fractions on idling performance of an n-butanol ignition engine with HDI. Fuel 2019, 258, 1-12. [CrossRef]

35. Li, G.; Yu, X.; Jin, Z.; Shang, Z. Study on effects of split injection proportion on hydrogen mixture distribution, combustion and emissions of a gasoline/hydrogen SI engine with split hydrogen direct injection under lean burn condition. Fuel 2020, 270, 117488. [CrossRef]

36. Yang, J.; Ji, C.; Wang, S.; Zhang, Z.; Wang, D.; Ma, Z. Numerical investigation of the effects of hydrogen enrichment on combustion and emissions formation processes in a gasoline rotary engine. Energy Convers. Manag. 2017, 151, 136-146. [CrossRef]

37. He, L.; Jingyuan, L.; Yu, X.; Mengliang, L.; Tian, Y. Numerical study on combustion and emission characteristics of a PFI gasoline engine with hydrogen direct-injection. Energy Procedia 2019, 158, 1449-1454. [CrossRef]

38. Liu, Y.D.; Jia, M.; Xie, M.Z.; Pang, B. Enhancement on a skeletal kinetic model for primary reference fuel oxidation by using a semi decoupling methodology. Energy Fuel 2012, 26, 7069-7083. [CrossRef]

39. Available online: http://www-cms.llnl.gov/combustion/archive.html (accessed on 20 June 2017).

(C) 2020 by the authors. Licensee MDPI, Basel, Switzerland. This article is an open access article distributed under the terms and conditions of the Creative Commons Attribution (CC BY) license (http://creativecommons.org/licenses/by/4.0/). 